\title{
Development Cooperation as a Foundation of Japan's Foreign Policy
}

\author{
TSUKASA TAKAMINE*
}

This paper addresses the question of what do Japanese foreign policymakers exactly mean when they repeatedly state that development cooperation has been, and still is, a foundation of postwar Japanese foreign policy, through a case study of Japan's official development assistance (ODA) towards China. More particularly, it investigates the complex policy objectives of Japanese ODA and the broader interests behind it, in order to clarify roles and significance of development assistance within Japan's overall foreign policy. My research demonstrates that despite its inherently economic nature, Japan's ODA provision to recipient countries has in application been more politico-strategic than commercial. Thus, it supports the point that development cooperation has undoubtedly been a foundation of postwar Japanese foreign policy.

Keywords: Foreign Policy, Development Assistance, Policy Objectives, National Interests, Economic Integration

\footnotetext{
* Assistant Professor of Politics in the Department of Integrated Arts and Science at Okinawa National College of Technology, 905 Henoko, Nago, Okinawa, JAPAN. Phone No.: +81 980554235 takamine@okinawa-ct.ac.jp
} 


\section{INTRODUCTION}

$\mathrm{J}$

apan was the world's largest provider of official development assistance (ODA) during most of the 1990s. However, in 2001, for the first time since 1992, Japan lost its position as the biggest bilateral donor, in volume terms. According to the latest figures by the Organization for Economic Cooperation and Development (OECD), in 2007 Japan was the fifth largest bilateral donor after the United States, Germany, France and the United Kingdom. In fact, in the same year Japan's ODA disbursement in net terms (US\$7.7 billion) was about only one third of that provided by the United States (US $\$ 21.8$ billion) (OECD 2008). ${ }^{1}$ With respect to multilateral aid provision, in 2008 Japan was ranked outside the top-ten position although it had steadily kept the top-three position throughout the 1990s. Furthermore, according to the director of the Economic Cooperation Bureau of the Japanese Ministry of Foreign Affairs (MOFA), which controls most of the aid budget, Japan's annual ODA budget has sharply decreased by about 40 per cent over the past decade (Kidera 2008).

Japan's ODA budget cut in the 2000s is a sign of increasing public concern about the efficient and effective use of ODA, in light of the decade-long recession between 1992 and 2001 that resulted in the large scale fiscal deficit and rising unemployment. Moreover, the so-called the Koizumi Reform implemented during the first half of the 2000s under the strong leadership by Prime Minister Koizumi Junichirō (2001-2006) led to consistent and large decreases in Japan's overall ODA budget. ${ }^{2}$ This reform that aimed at revitalizing Japanese economic strength through a series of radical administrative and fiscal reforms, did not allow Japanese aid agencies to escape from being a target of budget cut.

Given the negative developments on the ODA budget, Japanese foreign policymakers, in particular those working in the MOFA, are now seriously concerned about the substantial demise of Japan's overall diplomatic power (Kusano 2008). ${ }^{3}$ These policymakers think that Japan is losing not only its status as an aid superpower, but also a crucial foreign policy instrument that has been available for the country over the past half a century. The question arises as to what do Japanese foreign policymakers exactly mean when they state that ODA has been, and still is, a foundation of postwar Japanese foreign policy. This paper seeks to answer that question by looking at a case of Japan's ODA provision to China, in depth. More particularly, it investigates the complex policy objectives of Japanese ODA to China from 1979 to the early 2000s and the broader interests behind it, in order to clarify roles and significance of development assistance within Japan's overall foreign policy.

My study demonstrates that first, Japan's policy of providing ODA to China has been intended to promote various perceived Japanese economic, political and strategic interests. Second, it is shown here that policy objectives have evolved according to certain changes in the international and domestic environments. 
While some of the economic objectives that Japan has pursued through ODA provision to China have remained static, political and strategic goals have dramatically changed during the period in question. In particular, several external and internal developments that occurred between 1989 and the mid-1990s-that is, the Tiananmen Square massacre, the end of the Cold War international system, Japan's attachment of political conditions to its ODA provision, the shift in balance of China-oriented ODA policymaking power from Foreign Ministry bureaucrats to Liberal Democratic Party (LDP) parliamentarians, and the significant progress in Chinese economic development-contributed to the change in Japanese policymakers' perceptions of China, and eventually led to changes in the goals of Japanese ODA and the interests behind the provision of aid.

My study also suggests that despite its inherently economic nature, Japan's ODA provision to recipient countries has in application been more politico-strategic than commercial. In the end, provision of development aid is a proactive diplomacy on the part of Japan. As the second-largest economy in the world it has the option of using its large financial and technological capability for the purpose of engaging and influencing recipient countries. On the other hand, it has considerable domestic and external constraints on its freedom of action in security matters such as Article 9 in the Constitution and the US-Japanese Defence Treaty. ODA has been a very useful non-military strategic instrument for Japan in promoting its broad national interests in relation to recipient countries, including, in this case, China. Thus, this research supports the point that ODA has undoubtedly been a foundation of postwar Japanese foreign policy.

The first section reviews relationships between development assistance and foreign policy from donor's perspective to clarify the theoretical standpoint of this paper. The second section examines the actual policy objectives of Japanese ODA to China and the broader political, strategic and economic interests behind it during the decade between 1979 and 1988. The third section analyzes the international and domestic developments that produced changes in the policy objectives of Japanese ODA to China between 1989 and the mid-1990s. The fourth section evaluates the new policy objectives of Japan's China-oriented ODA, from the mid-1990s onwards, with reference to the actual implementation of the aid programme.

\section{DEVELOPMENT ASSISTANCE AND FOREIGN POLICY}

Before examining Japan's ODA to China in detail, this section reconsiders relationships between development assistance and foreign policy to help understand roles and significance of ODA within Japan's overall foreign policy. In doing so, the section is informed by existing studies about concept and practice of development assistance. 
As the Development Assistance Committee (DAC) of the OECD defines clearly, ODA is concessional funding provided by official agencies of developed countries for the purpose of developing economy and promoting welfare of developing countries (Poats 1986). The normative expectation behind ODA, which is also emphasised by the DAC, is that 'rich governments should provide economic resources to poor ones while leaving aside any commercial, political, and strategic considerations in order to maximise their developmental impact (Arase 1995, 9).' Despite this expectation, however, donor countries are in practice strongly interested in how and for what purpose their money and other resources are used in recipient countries. In fact, ODA is not 'an end in itself' but is 'an integral component' of the foreign policy of donor countries (Morgenthau 1962, 301-9). Unlike trade and foreign direct investment, which are primarily transactions by private businesses, ODA, whose source of funds is mostly taxpayers' money from donor countries, can hardly be separated from the foreign policy of the donor countries. ODA policies of major industrialised countries are largely "influenced by different combinations of foreign policy interests," (Schrader, Hook and Taylor 1998, 319).

Some analysts emphasise the importance of cultural influences on Japanese and Western aid activity, particularly in terms of motivation. With reference to the different socio-cultural contexts in Japan and Western countries, for example, "the sense of noblesse oblige which forms an important part of the rationale of the aid programs of the West is said [by some observers] to be absent from that of Japan," (Wright-Neville 1991, 37; Nakane 1972, 159-62). This distinction between Japanese foreign aid, which is supposedly self-serving, and that of the West, which is said to be based on noblesse oblige, is, however, easily challenged by many empirical cases of Western foreign aid activity. France has used a significant amount of its ODA for the purpose of French-language education in its former colonies in Africa to maintain its cultural influence over these countries (Schrader, Hook and Taylor 1998). From the late 1970s to the late 1990 s, the United States directed more than a third of its total foreign aid to only two countries-Israel and Egypt-each of which is a very important country for US Middle East strategy (Clarke 1997; Inada 1987). One Australian official admitted that Australia's aid to China is a very useful tool to promote Australian firms' commercial interests in China (Levy 1993). The concept of noblesse oblige cannot explain the political, strategic and commercial interests clearly visible behind these Western countries' foreign aid activities.

Humanitarianism surely is one of the philosophical motivations of donor nations in giving foreign aid, and every year a considerable amount of Western and Japanese ODA funds is used for the purpose of emergency and poverty relief, food production, education and medical help in many developing countries (Sawada and Yamada 2003). However, while humanitarianism may not be the least important objective of Western and Japanese ODA policies, it is almost certainly 
not the prime motivation (Mesquita and Smith 2009). On the basis of their comparative analysis of American, Japanese, French and Swedish aid flows, Schrader, Hook and Taylor conclude that 'our findings discounted the role of humanitarian need in the aid policies of these industrialised democracies' (1998, 13). In reality, it is very difficult for donor governments to implement aid policies on a humanitarian basis when those governments are operating in the competitive global sphere. In actual practice, ODA can serve a variety of foreign policy objectives. In short, it is a 'flexible but widely misunderstood policy instrument.' Further, as David Arase observes, 'because it is so flexible, it is impossible to determine without reference to a donor's broader interests which purpose, or priority of purposes, will likely motivate that donor's interests' (Arase 1995, 14).

Thus, the aim of this paper is not to examine success of a donor to help achieve targeted developmental goals in recipient countries, but to clarify foreign policy interests of a donor in relation to a country that receive that donor's aid.

\section{POLICY OBJECTIVES AND INTERESTS}

As will be argued below, the major aim of Japan's development assistance to China during the first decade of Japan's ODA program to China (1979-1988) was to support China's Reform and Liberalisation Policy. Nevertheless, Japan supported this policy not because it wanted to assist in the development of the Chinese economy and maintain the peace of the region for altruistic reasons, but rather to advance its own political, strategic and economic interests in relation to China.

\section{Political and strategic interests}

Between 1979 and 1988, the Japanese government made an effort to support the domestic political power of reformist Chinese leaders through ODA to China. To achieve this objective, Japanese governments actively supported the implementation of the Reform and Liberalisation Policy, by means of official development assistance (Arase 2006; Interviews with Inada and Soeya 2001). Reformist Chinese leaders such as Deng Xiaoping, Hu Yaobang and Zhao Ziyang were a major driving force of the Reform and Liberalisation Policy and, therefore, the success of the policy was crucial for their leadership within the Chinese government. Failure of the policy would not only threaten the authority of such reformist leaders, but would also suggest the possibility that more conservative leaders might usurp the reformists. In this context, it is no coincidence that the Japanese government began providing ODA to China a year after the in- 
troduction of China's new policy.

The support of reformist Chinese leaders was clearly in Japan's political interest as they were more likely than conservative leaders to guide the PRC in an open, liberal and cooperative direction through further reform of the Chinese economic system. The successful implementation of the Reform and Liberalisation Policy was also in Japan's economic interest, as it would further open the Chinese economy and consequently create lucrative trade and investment opportunities for private Japanese companies in China.

The major strategic interest that Japanese governments pursued through ODA provision to China between 1979 and 1988, when the Cold War still dominated international relations were first, to separate China economically from the Communist camp led by the Soviet Union. Through the provision of ODA to China, Japanese leaders aimed eventually to bring the country into the free world bloc, by significantly increasing the PRC's foreign aid and trade dependence on Japan. The introduction of the Reform and Liberalisation Policy by the post-Mao Chinese government in 1978 provided an excellent opportunity for the Japanese government to implement its long-held policy of economic engagement with China (Interview with Inada 2001). Although Prime Minister Yoshida Shigeru (1946-47, 1948-54) had desired to implement this policy at the beginning of the $1950 \mathrm{~s}$ in order to separate the PRC economically from the Soviet Union, it was impossible to do so because of strong opposition by the US government and China's self-reliant development policy. However, the situation changed with the 1971 Sino-American détente and the introduction of the Reform and Liberalisation Policy. Japanese ODA has indeed contributed to an increase in China's trade and technological dependence on Japan and on Western countries and, hence, eventually did help separate China economically from the Communist bloc.

Between 1979 and 1988, Japanese ODA to China also had security implications for both countries, given the Soviet Union's rapid military build-up in the East Asian region. That is, through economic cooperation, Japan supported China's military effort to counter the Soviet military forces along its long borderlines (Orr 1990). During this period of the Cold War, the United States government treated China as an informal American ally against the Soviet Union and actively provided various forms of military support to China, including the transfer of some defence technology. Thus, it is no surprise that as a formal American ally, Japan also treated China as its de facto ally against the Soviet Union. As one Japanese defence analyst remarks, a de facto anti-Soviet alliance between Japan and China had already existed throughout the 1970s and the 1980s (Kayahara 2001). During this period, the Japanese and the Chinese government even regarded each other's military build-up favourably. For example, Beijing did not object to the future renewal of the Japan-US security alliance in 1972, when the two countries normalised their diplomatic relations, and Deng Xiaoping and other 
Chinese leaders even encouraged a Japanese military build-up in the 1980s (Tow 1983; Kokubun 2006). In this context, Japan attempted to use ODA toward China in order to promote its security interest in the region in the Cold War strategic environment.

The other major objective that Japanese policymakers pursued between 1979 and 1988 was to help maintain stability in China's political and economic affairs through the provision of ODA. Like China's other neighbours, Japan was concerned about political and economic collapse in China, which could conceivably cause territorial fragmentation, civil war, and a resultant outflow of millions of Chinese refugees towards Japan and other neighbouring countries (Yee and Storey 2002). There is no doubt that such an outflow of refugees from a chaotic and collapsed China would put a severe strain on the limited resources of other countries. In view of China's population of 1.3 billion, any breakdown of the Chinese economy and society would inevitably have a negative impact not only on Japan, but also on the region and indeed the whole world (Katō 1997). From this perspective, instability in China's political and economic affairs posed a threat to Japan, and thus, was naturally a cause for concern for Japanese policymakers. One can conclude that Japan provided ODA partly to help prevent China from disintegrating.

It is also clear, however, that the emphasis by Japanese officials on the potential inflow of Chinese refugees into Japan in this period was rhetorical, or at least represented an exaggerated argument, intended to gain the public's support for aid activity to China (Kat̄̄ 1997). Apart from this broad perception of the threat from a collapsed China, there were several more precise reasons why Japanese policymakers feared instability in China's political and economic affairs. Japanese policymakers had commercial reasons for wanting to sustain stability in China. As one senior MOFA official commented, 'a disintegrated and unruly China would inevitably increase trade and investment risks for private Japanese companies and thus damage Japanese commercial interests involved with China,' (Interview with F 2001). Without political stability and economic growth, it was highly unlikely that the PRC would have been able to provide Japanese companies with either trade or investment opportunities.

Japanese policymakers also believed that a politically and economically chaotic China was likely to adopt aggressive foreign and military policies. The history of the PRC certainly suggests that chaos in domestic politics can precipitate radical and aggressive foreign policy. During both the Great Leap Forward (1958-1960) and the Cultural Revolution (1966-1976), Chinese foreign and security policy had largely been dominated by radical ideology, rather than the accepted rules and norms of orthodox international relations. As a result, China's foreign and defence policy towards Japan and other countries became very aggressive, and China experienced profound international isolation during both periods (Chūgoku sōran henshū iinkai 1978). Japanese observers are keenly 
aware that Chinese leaders, especially when involved in a domestic power struggle, have tended to adopt a foreign policy that benefits their domestic power, even if it undermines state interests and endangers foreign relations.

Furthermore, Japanese officials believed that if China became fragmented and chaotic, anti-Japanese nationalism among the Chinese public would increase because the restraining hand of the Chinese Communist Party would be removed or weakened (Interview with F 2001). They particularly feared a large increase in the number of war reparations claims made against the Japanese government by Chinese war victims. ${ }^{4}$ Such a situation constituted a worst case scenario for the Japanese government (Hasegawa and Watanabe 1995). In this context, the Chinese Communist Party's ability to use its political authority to control the escalation of anti-Japanese nationalism within China, often exercised in the past, was, and in fact is still, very useful for the Japanese government.

The irony of Japan's China-oriented ODA is that it has functioned to support the continuation of one-party political control by the Chinese Communist Party through its assistance to Chinese economic development. Nevertheless, this does not mean that the Japanese government is uncritical of the Communist Party's political dictatorship in China. Rather, the Japanese government does not want drastic and rapid change in the Chinese political system that might produce chaos in political and economic affairs. The Japanese government has in fact favoured the democratic transformation of the Chinese political system-but only if it progresses step by step without political upheaval and economic damage (Amako 2000). Japan's active support of the Reform and Liberalisation Policy, which had "already placed China on the road to reform and openness," (Kesavan 1990,681 ). through development assistance can also be understood in this context.

In the end, it is in Japan's politico-strategic interests to promote a stable and open China. Maintaining the stability of Chinese domestic affairs was thus an important aim of the Japanese government in implementing its development assistance policy to China between 1979 and 1988.

\section{Economic and resource interests}

Apart from the politico-strategic interests discussed above, Japanese governments also pursued certain considerations of economic self-interest through the provision of ODA to China between 1979 and 1988. However, it was not a straightforward case of pursuing narrow commercial advantage.

The dominant view of Japanese foreign aid activity is that it aims to provide commercial opportunities for privare Japanese companies (Schrader, Hook and Taylor 1998; Ensign 1992). On the basis of this perception, when the Ōhira Masayoshi government (1978-1980) announced that it planned to initiate government-level economic cooperation with China in 1979, the US and French governments quickly expressed their concern about the likely increase in Japan's economic 
presence in China. Contrary to US and French expectations, however, the Ōhira government made Japan's first yen loans to China untied (Yanai 1980). As the provision of untied yen loans provided Japanese companies and their Western competitors with an equal opportunity to sell their plant and machinery to China, the commercial interests of private Japanese business would be minimised rather than advanced. Thus, if the major aim of Japanese ODA to China was to benefit private Japanese companies commercially, then this decision by the Ōhira government is difficult to comprehend (Economic Cooperation Bureau 1991). Indeed, the major economic aims Japan pursued through the provision of foreign aid to China between 1979 and 1988 were not to advance the narrow and immediate commercial benefits of private Japanese companies through ODA project contracts, but rather to access China's energy resources and markets and, hence, to advance broader and longer-term national economic interests.

The economic self-interest that Japan chiefly pursued through its ODA policy regarding China during the first decade after the start of the policy was to secure a stable supply of Chinese oil and coal for Japan. The specific international environment of the 1970s particularly encouraged Japan to diversify its import sources of oil and coal. The 1973 oil shock, caused by the large reduction of oil exports from the petroleum-producing Arab countries to industrialised countries, brought about tremendous panic among the Japanese public. Furthermore, the second oil shock in the late 1970s-that is, the sharp oil price increase and uncertainty of supply caused by political upheaval in Iran-undermined Japanese industrial operations (Ōkita 1979). As stable access to oil and oil products was crucial for both the Japanese industrial and consumer sectors, the oil shocks presented a challenge for Japanese energy security. Given the oil shocks, Japan not only began to pay more attention to alternative energy resources, including nuclear energy, but also started to diversify its import sources of oil to reduce its large dependence on the Arab countries. Besides Indonesia, China was the closest and cheapest source of oil and coal imports for Japan. To ensure the supply of oil and coal, Japan actively provided a large portion of its yen loans for the development of that part of China's industrial infrastructure that facilitated the export of these resources to Japan, including railroads and ports (Asabi shinbun, 1 December 1979). As most of the first yen loan package to China was used to construct such transport infrastructure, Japan's need to secure energy imports had largely been met by the late 1970s (Asabi shinbun, 4 December 1979).

Apart from securing a stable supply of energy resources, Japan also pursued trade and investment interests in China through provision of ODA funds between 1979 and 1988. During this period, yen loan projects were concentrated on the development of transportation, energy and telecommunication infrastructure in China. These developments in turn helped promote Japanese business investments by reducing investment costs for those private Japanese companies that 
were seeking new markets.

The level of Japanese direct investment in China certainly did increase from US\$22 billion in 1984 to US\$51 billion in 1988 (JETRO 2000). In turn, the increase in investments facilitated Sino-Japanese trade, which rapidly increased from US $\$ 10$ billion in 1983 to US\$13 billion in 1984 (Tanaka 1991). Furthermore, in 1985, Japanese exports to China doubled in the first half of the year compared to the same period in the previous year, reaching US\$60 billion. China thereby became the second largest destination of Japanese exports after the United States. By 1988, trade with Japan consisted of more than 20 per cent of China's total trade (Tanaka 1991). Though it is impossible to pinpoint the exact causes of the increase in trade, it seems clear that the provision of the first and second yen loan packages between 1979 and 1988, together with the Japanese investment which followed, was partly responsible, as was the generally good state of bilateral relations at the time.

Thus, during the period of 1979-1988, the first decade of Japan's ODA implementation toward China, ODA arguably helped to deepen economic interdependence and to diversify economic relations between Japan and China, while also advancing Japanese trade and investment intersests.

\section{CHANGING POLICY OBJECTIVES: A TRANSITIONAL PERIOD}

Despite the smooth implementation of ODA to China between 1979 and 1988, a number of international and domestic developments between 1989 and the mid-1990s encouraged Japanese policymakers to reassess the perceived national interests that Japan had pursued through the ODA policy toward China. Such reassessment eventually led to changes in the policy objectives of China-oriented ODA after the mid-1990s. This section examines the security risk embedded in Japan's ODA to China, the impact of the end of the Cold War and of the China threat thesis, the 1992 launch of Japan's ODA Charter, and the shift in the balance of ODA policymaking power between the MOFA and the LDP. The period from 1989 to 1994 , in short, can be regarded as a transitional period in which a re-evaluation of the Japanese interests pursued through ODA to China was gradually undertaken.

\section{The security risk embedded in development assistance}

The Tiananmen Square massacre had significant implications for ODA policy toward China in the 1990s. First, the Chinese government's abuse of human rights in Tiananmen Square undermined Japanese policymakers' idealism about modernising China, which was expected to have become more open and moderate. 
It forcefully reminded Japanese policymakers of the diplomatic and security risk embedded in Japan's program of aid to China, which had, after all, supported the modernisation program of a strong authoritarian regime. For example, one senior Foreign Ministry bureaucrat remarks:

In the decade before the 1989 Tiananmen Square massacre [1979-89] there had been a broader consensus among the Japanese public and politicians in favour of providing full support for China's modernisation. Given the changed domestic and international environment since then [the post-Tiananmen resentment of the Chinese government among the Japanese public, the rapid militarisation of China and the end of the Cold War], we will respond on a case-by-case basis to any disruptive behaviour by Beijing that could damage Japanese interests (Interview with F 2000).

This change in Japanese policymakers' perception of China has become a very important factor leading to changes in the implementation of Japan's ODA policy toward China since the mid-1990s.

Second, Japan's ODA sanction, which was applied for the first time to China at the time of the massacre, revealed a new diplomatic option for Japanese policymakers. The surprising vulnerability of the Chinese government to aid sanctions applied by Japan and Western countries caused Japanese policymakers to reflect on the usefulness of ODA sanctions as a diplomatic instrument against recipient countries, including China (Katada 2001). In the face of sanctions, the Chinese government changed its commercial laws to make them favourable to Western and Japanese investors and freed jailed Chinese leaders of democratic movements less than one year after the Tiananmen Square massacre (Gaimushō keizai kyōryoku kyoku 1994). Despite Japan's lack of enthusiasm in applying ODA sanctions against recipient countries before the massacre, the number of Japanese ODA sanctions dramatically increased throughout the 1990s (Shimomura, Nakagawa and Saitō 1999).

Before the Tiananmen Square massacre, the major goal that the Japanese government had pursued through economic assistance to China had been to prevent China from fragmenting and becoming isolated. After the massacre, on the other hand, preventing China from becoming a dominant military power in the region also became an important objective of ODA policy (Inoguchi 1991).

\section{The end of the cold war and china threat thesis}

The profound change in the East Asian strategic environment following the end of the Cold War fundamentally affected Japan's ODA policy towards China. With the decrease in the Soviet military threat following the collapse of the Soviet Union at the beginning of the 1990s came the end of the de facto anti-Soviet

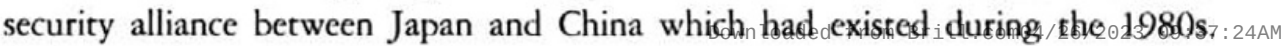


This led to a resurgence of the traditional Sino-Japanese strategic rivalry from the beginning of the 1990s onwards. Furthermore, China's rapid modernisation and the sharp increases in its military expenditure since the beginning of the 1990s caused consternation among Japanese policymakers about China's intentions in the region (Gaimushō Chūgoku-ka 2000). These dramatic changes in SinoJapanese strategic relations contribured to a reconsideration of the policy objectives of Japan's ODA policy toward China, and the strategic interests behind it.

From the beginning of the 1990s, the Chinese and Japanese governments started to regard each other's military development as a source of concern, largely because of the diminution of the common security threat formerly represented by the Soviet Union. In the 1990s, Beijing repeatedly condemned Japan's attempts to strengthen the Japan-US defence alliance, including revision of the Japanese Defence Guidelines and Japan's participation in the US ballistic missile defence (BMD) system development project, while the Japanese government became increasingly sensitive about China's military build-up and disruptive military behaviour in the region. The history of Japanese wartime aggression in China is one source of Chinese fear of Japanese militarisation (Beeson 2009; Christensen 1999), while the Chinese Communist Party's repeated human rights violations and aggressive policy towards Taiwan are sources of Japan's scepticism about the PRC's military build-up.

One clear manifestation of concern about Chinese military modernisation, grounded in the country's fast economic growth, is the so-called China threat thesis, which has been articulated in the Western and the Japanese academic community and media since the early 1990s (Nakajima 1997; Kato 1997; Kojima 1991). The China threat thesis first emerged in 1993 when the World Bank reported that, in terms of purchasing power parity (PPP) and if Hong Kong and Taiwan were included, China would surpass the United States in total GDP and become the world's largest economy by the year 2002 (Yee and Storey 2002). At the same time, the International Monetary Fund presented a similar report saying that in PPP terms, in 1992 China had already become the third largest economy in the world after the United States and Japan (Takagi 1994). These reports unnerved many analysts around the world who believed that China would quickly turn its enhanced economic capability into military power, and subsequently, fulfil the China threat thesis.

China's increased expenditure on its military budget and weapons acquisitions specifically, together with the lack of transparency in its military policy (Hiramatsu 1999), are the major sources of concern for proponents of the China threat thesis. Rapid economic development during the 1980s and 1990s gave the Chinese government considerable financial capacity to develop its military power by modernising both conventional and nuclear weapons. Since the beginning of the 1990s, China has indeed rapidly and consistently increased its military expenditure. In particular, there has been a large effort to modernise air and naval capabilities, 
which, if necessary, can be used to threaten neighbouring countries, especially those engaged in territorial disputes with China (NIDS 1999; Abe 1996; Kojima 1996). In fact, China is one of the few nations that has been rapidly increasing its military expenditure and consistently enhancing its nuclear and conventional military capabilities in the post-Cold War era (Ikenberry 2008; Narramore 2008), while other military powers, including the United States and Russia, have been cutting their defence expenditure and decreasing the number of their nuclear missiles. 5

Furthermore, Japanese critics, such as Komori Yoshihisa and Hiramatsu Shigeo, argue that the Japanese government has been indirectly assisting China's military development by providing ODA (Komori 2000). They contend that Japanese development assistance to the PRC has supported Chinese military power by indirectly subsidising the country's defence budget and by helping to construct many airports, ports, railways, highways and telecommunication facilities in China. These critics emphasise the point that this infrastructure can be used for military as well as civilian purposes.

The China threat thesis and the argument that Japan's ODA has assisted Chinese militarisation have undeniably contributed to increasing suspicion of the Chinese government's military ambitions in the region among Japanese politicians and the public since the early 1990s, and thus have influenced Japanese governments' ODA policymaking toward China (Kawashima 2003). In the 1990s, as a result, Japan's implementation of the China aid program became increasingly cautious.

\section{The launch of Japan's first $O D A$ charter}

Not only have changes in perceptions of China among Japanese policymakers and academics affected ODA policy to China, but the related attachment of clear political conditions to Japanese ODA provision in 1992 has also significantly changed the ODA approach to China. With the launch of an ODA Charter in 1992, Japan made the political and strategic aims of its ODA evident. The Four ODA Principles of the Charter began to be used as a critical diplomatic instrument to check China's military development and disruptive military behaviour in the East Asian region.

The ODA Charter was a statement of the underlying philosophy of Japanese ODA, expressed as a set of political conditions which would govern decisions about the provision of aid. It was produced in 1992 by the Ministry of Foreign Affairs, but only after significant pressure from the Liberal Democratic Party, which in turn was reacting to pressure from outside the Diet to make Japanese ODA more transparent and more explicitly responsive to the new international conditions of the early 1990s.

The ODA Charter states that after full consideration of each recipient country's 
requests, its socio-economic conditions, and its bilateral relations with Japan, ODA will be provided in accordance with the following four principles. First, environmental conservation and development should be pursued in tandem. Second, any use of ODA for military purposes or for aggravation of international conflicts should be avoided. Third, full attention should be paid to trends in recipient countries' military expenditures, their development and production of weapons of mass destruction and missiles, and their export and import of military armaments. Fourth, full attention should be paid to efforts to promote democratisation and the introduction of a market-oriented economy, and the situation regarding the preservation of basic human rights and freedoms in the recipient country (Economic Cooperation Bureau 1999). Unlike a law, the Charter is a flexible instrument whose application varies in actual practice. Nonetheless, the introduction of the Four Principles of Japanese foreign aid in 1992 did demonstrate Tokyo's determination to attach clear political conditions to its foreign aid activity. ${ }^{6}$

The most significant characteristic of the ODA Principles is that they openly expressed concerns over recipient countries' military build-up. Although other industrialised countries used their aid policies to express their concern about abuses of human rights in recipient countries, Japan was the first donor to explicitly connect military development with its foreign aid program (Shimomura, Nakagawa and Saitō 1999).

\section{Shifting balance of ODA policymaking power}

In addition to the external and internal developments explained above, another crucial development within the process of Japan's ODA policymaking also contributed to fundamental changes in the ODA policy objectives toward China. That is, the shift in the balance of China-oriented ODA policy-making power from Foreign Ministry bureaucrats to LDP parliamentarians. This shift, evident from the mid-1990s onwards, has significantly changed the perception of what Japan's political, economic and strategic interests are in relation to China, and thus has produced changes in the implementation of Japan's China-oriented ODA policy.

Before the mid-1990s, Japan's ODA policy, including policy toward China, was determined primarily by policymaking bargaining among central government ministries-the MOFA, the Ministry of Finance, the Ministry of International Trade and Industry and the Economic Planning Agency-each of which approaches the process of ODA policymaking largely from 'its own parochial interests,' (Orr 1990, 3). Japan's ODA policy was "built up on bureaucratic decisions and outcomes, ranging from determination of total aid volume goals to the type of funds committed to recipients and the terms on which they were provided." (Rix 1980, 12, 267).

Since the mid-1990s, Japan's ODA policy with regard to China has ceased 
to be determined primarily by policymaking bargaining among central government ministries, but rather has been determined chiefly by intense competition between the Liberal Democratic Party and the Ministry of Foreign Affairs. Following institutional and functional changes in both the LDP and the MOFA during the first half of the 1990s, the power to formulate ODA policy toward China has shifted dramatically from MOFA bureaucrats towards LDP parliamentarians. Various factors-the LDP's steady accumulation of foreign policymaking knowledge, its enhanced access to important diplomatic information previously monopolised by the MOFA, and the political will of LDP parliamentarians to take a leading role in ODA policymaking with regard to China-have contributed to this important development (Takamine 2002). While LDP politicians' intervention in the area of China-oriented ODA policymaking has become more frequent and effective, MOFA bureaucrats struggle to protect their already undermined autonomy. The dramatic shift in the balance of ODA policymaking power towards the LDP and away from the MOFA produced a change in the way that the Japanese government used ODA in its diplomatic dealing with China.

To sum up, the external and internal developments that impinged on SinoJapanese relations between 1989 and the mid-1990s-the Tiananmen Square massacre, the changed strategic environment, the attachment of political conditions to Japan's ODA provision, the shift in the balance of ODA policymaking power within the Japanese government-encouraged a reassessment of the interests pursued by Japan through its ODA policy toward China. During the period then, the fundamental goal behind Japan's China-oriented ODA policy gradually shifted from engaging a weak China (but a de facto military ally) to engaging a modernising China (that posed a potential military threat). This reassessment eventually led to the changes in the policy goals of Japanese ODA to China which became obvious after the mid-1990s.

\section{V. "NEW" POLICY OBJECTIVES AND INTERESTS}

Since the mid-1990s, there have been two major developments with regard to Japan's ODA policy to China. First, for several reasons the Japanese government has shifted the priority project areas of ODA to China from industrial to socio-environmental infrastructure development. Second, the incorporation of the Chinese economy into the market-based regional and global economic system, in particular into the World Trade Organization (WTO) framework, became a key policy goal of Japan's ODA.

\section{Shift in the priority project areas and its reasons}

Since the mid-1990s, the Japanese government has changed the major target project areas of China-oriented ODA. Instead of industrial infrastructure developict 
ment, the new focus is on environmental infrastructure development. More particularly, the major project areas of Japanese yen loans have shifted from the traditional areas of railways, ports, power plants, water supply, and sewerage construction to environmental protection, the improvement of food production and the development of inland provinces. For example, in 1996, eight environmental and three agricultural projects were included in the total list of twenty-two yen loan projects, worth a total of about $¥ 176$ billion. Among the total twenty-two projects, seventeen were in inland provinces. In 1997, six environmental and one agricultural project out of the total of fourteen projects, worth in all about $¥ 203$ billion, were carried out. Among the fourteen, eleven were implemented in inland areas (Chūgoku sōran henshū iinkai 1998). This trend towards yen loan provision for various environmental, agricultural and inland projects in China has continued: twenty out of the total of twenty-eight projects, worth in all $¥ 390$ billion, which were carried out in 1999 and 2000 were related to the environment or agriculture (Chūgoku sōran henshū iinkai 1998).

The Ministry of Foreign Affairs has stated that this shift in ODA policy is intended to help prevent the worsening of the socio-economic problems that have been created in the process of China's transition from a highly centralised planned economy to a more market-oriented one. Indeed, rapid economic growth in the 1980s and the first half of the 1990s, which Japanese ODA had helped to stimulate, did reduce the potential for instability in domestic affairs caused by China's economic backwardness and overall poverty. However, China's radical transformation into a market economy and the uneven distribution of wealth among its population in turn produced various socio-economic problems, including the widened income gap between inland and coastal provinces, massive unemployment created by the policy of closing uncompetitive state enterprises, the accumulation of non-performing loans in the private and state financial sectors, rapid environmental degradation, the absence of a social safety net for the unemployed, and more recently the lack of food and product safety (Duckett and Hussain 2008; Overholt 2000; Okada 1994; Amako 2001; Inoguchi 1996; Brown 1995; Krugman 1994; Economy and Segal 2009).

In the early 1990s, Japanese policymakers acknowledged that these new domestic problems would put great strain on the sustainability of China's economic development and, hence, were likely to undermine the stability of China's economic and social affairs in the near future (JICA 1999). Increasing numbers of unemployed Chinese people in urban areas have indeed become a destabilising factor in China's social and political affairs. Moreover, the Japanese government further explains that the change in the priority areas of China-oriented ODA partly constitutes an attempt to promote a more institutionalised market economic system in China, through the promotion amongst other things of macro control mechanisms, financial systems for market integration, a financial control system through a central bank, and an institutionalised social safety net for the unemployed 
(JICA 1999). In this context, the Japanese government is using ODA more to provide knowledge and expertise to help create a more institutionalised market economy in China, than for the development of further economic infrastructure.

Government pronouncements on this subject are more likely, however, to reflect official reasoning, or at least secondary objectives, that hide the real policy goals pursued by the Japanese government through its ODA policy toward China. In other words, they constitute the kind of rhetoric that is deliberately emphasised by the Japanese government in order to gain public support for the continuation of its China aid activity. The actual motives behind the Japanese government's decision to change the priority project areas of its ODA to China, from economic to social and environmental infrastructure development, are the evident progress in China's economic development, the budgetary interest of the Japanese Ministry of Foreign Affairs, and a consideration of Japan's security interests.

First, China's rapid economic development in the 1980s and early 1990s decreased the importance of Japanese ODA as a source of foreign aid to supplement China's shortage of domestic savings. Given the shortage in the 1980s of both domestic savings and foreign currency, Japanese ODA policymakers thought that the provision of ODA for construction of economic infrastructure was the most efficient use of development funds. By 1993, however, China's rapidly increasing trade surplus was responsible for vastly improved foreign currency reserves and domestic savings (Inada 2000). This meant that by that time the Chinese government already had a sufficient financial capacity to develop industrial infrastructure independently. Thus, according to the conventional wisdom of development economics, it was inevitable that the Japanese government would shift the priority areas of China-oriented ODA from industrial infrastructure development to other project areas (JIIA 2000).

Second, the strong need of Ministry of Foreign Affairs bureaucrats to protect their organisational interest also encouraged the shift in the priority project areas of Japanese development assistance to China. ${ }^{7}$ As ODA accounts for most of the Ministry's annual budget (Asabi shinbun, 29 August 2001), Foreign Ministry bureaucrats are keen to prevent any reduction of the ODA budget, including the budget for ODA to China (Katada 2004). Some opinion polls conducted between 1991 and 1996 revealed, however, that the Japanese public was reluctant to support any increase in the ODA budget. For example, according to one poll, the proportion of those who supported an increase in the overall ODA budget dropped from 41 per cent in 1991 to 33 per cent in 1996, while those who supported a cut in the ODA budget grew from 8 per cent to 13 per cent (Katada 2001). The overall ODA budget was reduced for the first time in 1996 by 10 per cent and, since then, the decline in public support for ODA activity has put significant pressure on the Japanese government to cut the 
budget further. In fact, the government decided to reduce the ODA budget by another 10 per cent in 2002 (Yomiuri shinbun, 20 December 2001). The economic recession that started in Japan at the beginning of the 1990s, and the resultant national budget deficit, has made Japanese taxpayers increasingly reluctant to allocate their money overseas.

With respect to Japan's ODA to China, the Japanese public was, in the early 2000s, taking a even more negative view, and was demanding a reduction in the China related ODA budget. For example, according to one opinion poll conducted by the Yomiuri shinbun, a Japanese daily newspaper in 2002, the proportion of Japanese who have a positive view of the government's China-oriented ODA activity over the last two decades was less than 22 per cent, while the proportion who view such ODA activity negatively was as high as 65 per cent. Moreover, in this poll, 56 per cent of the total respondents wished to either cut or cease the provision of Japanese ODA to China, while 36 per cent wished to maintain the current level or increase China-oriented ODA provisions (Yomiuri shinbun, 11 September 2001).

In the face of such domestic pressure to reduce the total ODA budget, the Ministry of Foreign Affairs was forced in the mid-1990s to shift the priority project areas of ODA to China, in an effort to sustain public support for the ODA policy. Since China's economic development has progressed to a considerable degree, it has become increasingly difficult for Foreign Ministry officials to justify continued assistance for infrastructure development. The shift towards social and environmental infrastructure development in China, which is based more on humanitarian need than economic need, has proved a very useful way of gaining public and parliamentary support for the continuation of ODA to China.

Third, the perceived new imperative for the Japanese government to restrain China's military development has also promoted the shift in the priority project areas of ODA to China. As explained above, the resurgent Sino-Japanese strategic rivalry and China's rapid military development, which became evident in the early 1990s, motivated Japanese policymakers to restrain the further militarisation of China. Moreover, the China threat thesis and the claim that Japanese ODA had indirectly contributed to the military development of China also made Japanese policymakers more aware of the indirect linkage between Japanese ODA and Chinese militarisation. Japanese policymakers were thus encouraged to change ODA funding areas in China to prevent Japanese ODA from indirectly assisting Chinese militarisation (Interview with Soeya 2001). Unlike the development of highways, ports, airports and telecommunication facilities which can also be used for military purposes, the provision of ODA for environmental conservation and poverty relief projects can hardly be linked with the military operations of the Chinese army (Hiramatsu 2000). 


\section{Integrating China into the WTO framework}

Since the mid-1990s, the integration of the Chinese economy into the market-based global economic system, particularly into the World Trade Organization (WTO) framework, has been a further policy goal of Japanese ODA to China. Prior to 1979, the major reason that many Japanese and Euro-American multinational companies did not invest in China was the absence of adequate industrial infrastructure. By contributing to the development of Chinese industrial infrastructure during the $1980 \mathrm{~s}$, Japanese ODA facilitated direct investments in China by Japanese and Euro-American companies. Consequently, China's foreign trade expanded and diversified and China's economic interdependence with these countries has significantly deepened. For Japanese policymakers, promotion of China's trade transactions with and foreign direct investment from a variety of countries was critical to their attempt to incorporate China into the market-based global economic system (Takamine 2006).

The first reason for Japan's efforts to incorporate China into the WTO framework was to encourage China to respect global economic norms and rules and base its behaviour on them, rather than on its own distinctive values and rules (Yomiuri shinbun, 28 August 2000). This would enable the two countries to negotiate and resolve any bilateral issue on the basis of accepted international rules. In other words, the Japanese government prefers to handle China within multilateral frameworks, rather than to do so by itself. Second, Japanese governments have also sought to facilitate China's transition from a highly centralised socialist economy to a more market-oriented economy. In fact, in March 1999, Chinese leaders changed the Constitution to allow 'individual and private ownership,' an important aspect of the market economy (Economic Cooperation Bureau 2000). The transition of China to a more market-oriented economy is considered to be in Japan's political as well as economic interest, as it would guide China in a more open and liberal direction, in the long run.

The Hashimoto and Obuchi governments made particularly large efforts to convince both Chinese leaders and other OECD countries to take a positive approach towards China's acquisition of WTO membership during the second half of the 1990s. For example, the Hashimoto government reached an agreement with the PRC over trading goods in September 1997 and the Obuchi government reached a service trade agreement with the PRC in July 1999. Four months later, Australia and the United States established similar trade agreements with the PRC (Gaimushō Chūgoku-ka 2000). On 11 December 2001, the WTO officially announced China's membership. China's entry into the WTO system provided private companies from Japan and elsewhere with further investment and export opportunities. According to figures from the International Monetary Fund (IMF), Japanese exports to China increased 61 per cent from US\$29.7 billion in 1998 to US\$48.5 billion in 2002, while the US exports to ${ }_{2}$ China 
increased 54 per cent during the same period from US $\$ 38.0$ billion to US $\$ 70.1$ billion (IMF 2003). Japanese governments strongly supported China's acquisition of WTO membership because it is seen to be not only in Japan's economic interests, but also its strategic interests because it is likely to make China a more constructive partner in the global system (Whiting 2001).

\section{CONCLUSION}

My research indicates that Japan used ODA as a crucial diplomatic tool to promote various perceived foreign policy interests in relation to China. During the 1980s, when the Chinese economy was comparatively underdeveloped and poverty was a significant threat to social stability, the major aims of Japan's provision of ODA to China were first, to assist in stabilizing China's economic and social affairs by actively supporting the government's Reform and Liberalization Policy, through financial and technological assistance for industrial infrastructure development. The second aim was to support the integration of the Chinese economy into the market-based regional and global economic systems by promoting a market economy in China and by promoting China's trade with, and foreign direct investments from, Japan and other countries around the world. During the first decade of the China-oriented ODA program, therefore, Japanese governments mostly used ODA as a financial and technological tool in their attempt to promote a domestically stable and internationally engaged China, the emergence of which was construed to be in Japan's own strategic, political and economic interest.

My research also shows that the policy objectives of Japan's ODA policy toward China had changed by the mid-1990s, by which time Chinese economic development had progressed significantly. The strategic relations between Japan and the PRC had radically altered following the Tiananmen Square massacre and the end of the Cold War international system. Japan had attached clear political conditions to its foreign aid provision through the ODA Charter of 1992, and the balance of China-oriented ODA policymaking power had dramatically shifted from Foreign Ministry bureaucrats to Liberal Democratic Party parliamentarians.

Since the mid-1990s, one major aim of Japan's ODA to China has been to incorporate China into the WTO framework, hence into the market-based global economic system. At the same time, the Japanese government, on the basis of certain financial and strategic considerations, has also started to shift the priority areas of its ODA to China from industrial infrastructure development to social infrastructure development, including environmental protection, poverty relief, and the development of inland provinces to narrow the income inequalities between the people of the coastal and the inland regions.

The various policy objectives pursued by Japan'sow $O D A_{d}$ policy r to . Chinae described $7: 24 \mathrm{AM}$ 
above illustrate the striking flexibility of Japanese ODA as a foreign policy instrument. Despite its inherently economic nature, Japan's ODA provision to China has in application been more politico-strategic than commercial. In the end, provision of China-oriented ODA is a proactive foreign policy on the part of Japan, which has the option of using its large economic and technological capability for the purpose of engaging recipient countries, and which on the other hand has significant domestic and external constraints on its freedom of action in security matters, especially the peace clause in the Constitution.

Findings of my research support that ODA has undoubtedly been a foundation of postwar Japanese foreign policy in the sense that it has functioned as a very useful non-military strategic instrument in promoting Japan's broad diplomatic, economic and security interests in relation to recipient countries. This explains why Japanese foreign policy policymakers are now so fearful about the sudden and substantial demise of Japan's aid power which has become obvious in the first decade of the $21^{\text {st }}$ century.

\section{REFERENCES}

Abe, Junichi. 1996. Kaiyō o mezasu Chūgoku no gunji senryaku (China's Military Strategy Aiming at the Ocean). Kokusai mondai 430: 58-73.

Amako, Satoshi. 2000. Seiji taisei no kōzō teki henyō (Structural Change in the Chinese Political System) in Gendai Chūgoku no kōzō hendō (Structural Change in Contemporary China), ed. Mōri Kazuko. Tokyo: Tōkyō daigaku shuppan-kai.

Amako, Satoshi. 2001. Chūgoku, Tenanmon jiken to sōgō kokuryoku (China, the Tiananmen Square Incident and Comprehensive National Power). Sekai 687: $146-51$.

Ampiah, Kweku. 1988. A One Sided Partnership. West Africa 28(4): 2221-38. Arase, David. 1995. Buying Power: The Political Economy of Japan's Foreign Aid London: Lynne Rienner Publishers.

Arase, David. 2006. Japanese ODA Policy towards China: the New Agenda in Japan's Relations with China: Facing a Rising Power, eds. Peng Er and Lam. London and New York: Routledge.

Asabi shinbun (A Japanese daily newspaper). 1 December 1979.

Asabi shinbun (A Japanese daily newspaper). 4 December 1979.

Asabi shinbun (A Japanese daily newspaper). 29 August 2001.

Atwood, J. Brian, Peter. M. McPherson, and Andrew Natsios. 2008. Arrested Development: Making Foreign Aid a More Effective Tool. Foreign Affairs 87(6): 123-33.

Beeson, Mark. 2009. Institutions of the Asia-Pacific: ASEAN, APEC and beyond. London and New York: Routledge. 
Brown, Lester. 1995. Who Will Feed China? New York: Norton.

Christensen, Thomas J. 1999. China, the US-Japan Alliance, and the Security

Dilemma in East Asia. International Security 23(4): 49-80.

Chūgoku sōran henshū iinkai. ed. 1978. Chūgoku sōran 1978. Tokyo: Zaidan hōjin kazankai.

Chūgoku sōran henshū iinkai. ed. 1998. Chūgoku sōran 1998. Tokyo: Zaidan hōjin kazankai.

Clarke, Duncan L. 1997. US Security Assistance to Egypt and Israel: Politically Untouchable?. Middle East Journal 51(2): 200-14.

Development Assistance Committee, OECD. 1995. Recommendation on Financial Terms and Conditions in 1969. cited from Buying Power: The Political Economy of Japan's Foreign Aid. David Arase. London: Lynne Rienner Publishers.

Duckett, Jane and Athar Hussan. 2008. Tackling Unemployment in China: State Capacity and Governance. Pacific Review 21(2): 211-230.

Economic Cooperation Bureau. 1991. Ministry of Foreign Affairs, Japan's ODA 1990, Tokyo.

Economic Cooperation Bureau. 1994. Ministry of Foreign Affairs, Japan's ODA 1993, Tokyo.

Economic Cooperation Bureau. 1999. Ministry of Foreign Affairs, Japan's ODA 1998, Tokyo.

Economic Cooperation Bureau. 2000. Japanese Ministry of Foreign Affairs, Japan's Official Development Assistance Annual Report 1999. Tokyo.

Ensign, Margee M. 1992. Doing Good or Doing Well? Japan's Foreign Aid Program. New York: Columbia University Press.

Gaimushō Chūgoku-ka (China Division, Ministry of Foreign Affairs). 2000. Saikin no Chūgoku jōsei to Nitchū kankei (Current Chinese Affairs and Japan-China Relations)'. Unpublished report.

Gaimushō keizai kyōryoku kyoku (Economic Cooperation Bureau, Ministry of Foreign Affairs). 1994. Wagakuni no seifu kaibatsu enjo 1994 (Japan's ODA 1994). Tokyo.

Hasegawa, Keitarō, and Toshio Watanabe. 1995. Yōsō no chōtaikoku Chūgoku (Myth of Superpower Cbina). Tokyo: Tokuma shoten.

Hiramatsu, Shigeo. 1999. Chūgoku no gunji ryoku (China's Miliatry Capability). Tokyo: Bunshun shinsyo.

Hiramatsu, Shigeo. 2000. Chūgokugun o tsuyokusuru ODA (The ODA which Makes the Chinese Military Stronger). Seiron November 2000: 152-60.

Hiramatsu, Shigeo. 2000. Tai-Chū ODA, gun-min ryōyō no jittai (The Military-Civilian Dual Use of Japanese ODA by China). Tбa 400: 6-21. Ikenberry, G. John. 2008. The Rise of China and the Future of the West. Foreign Affairs 87(1): 23-37.

IMF (International Monetary Fund). 2003. Direttion of Trade Statistics. Washington DC: IMF. 
Inada, Jūichi. 1987. Nihon gaikō ni okeru enjo mondai no shosokumen (Several Aspects of Foreign Aid Issues in Japanese Diplomacy). Kokusai mondai 326: $2-20$.

Inada, Jūichi. 2000. Tai-Chū ODA no keizaiteki shakaiteki hyōka ni tsuite (An Economic and Social Assessment of China ODA) in Tai-Chū ODA no keizai sakai inpakuto ni tsuiteno kisoteki chōsa (Basic Research on the Economic and Social Impact of China ODA), ed. Nihon kokusai mondai kenkyūjo. Unpublished report. Tokyo.

Inoguchi, Takashi. 1991. Japan's International Relations, Boulder: Westview Press. Inoguchi, Takashi. 1996. Kaibutsu Chūgoku ni dō tsukiau noka? (How Should We Deal with a Monster China?). This is Yomiuri 7(6): 34-45.

Interview with F. 2000. A senior official of the Japanese Ministry of Foreign Affairs. Tokyo. 20 April.

Interview with F. 2001. A senior official of the Japanese Ministry of Foreign Affairs. Tokyo. 14 March.

Interview with Jūichi Inada. 2001. A political economist at Senshū University and a senior research fellow at the Japan Institute of International Affairs. Tokyo. 28 March.

Interview with Ryōsei Kokubun. 2001. A specialist on Chinese politics, professor and director of the Centre for Area Studies at Keiō University. Tokyo. 15 March.

Interview with Yoshihide Soeya. 2001. A political scientist specialising in Sino-Japanese relations at Keiō University. Tokyo. 28 March.

JETRO (Japan External Trade Organization). 2000. Chūgoku deita fairu 1999/2000 (China Data File 1999/2000). Tokyo.

JICA (Japan International Cooperation Agency). 1999. Chūgoku kunibetsu enjo kenkyū-kai bōkoku-sbo: dai niji (Second Report by the China Aid Research Group). Tokyo. 15-25.

JIIA (Japan Institute of International Affairs) ed. 2000. Tai-Chū ODA no keizaiteki shakaiteki inpakuto ni tsuite no kisoteki chōsa (Basic Research on the Economic and Social Impact of China ODA). Unpublished report. Tokyo.

Katada, Saori N. 2001. Why Did Japan Suspend Foreign Aid to China? Japan's Foreign Aid Decision-making and Source of Aid Sanction. Social Science Japan Journal 4(1): 39-58.

Katada, Saori N. 2004. New Cources in Japan's Foreign Aid Policy: More Humanitarian and More Nationalistic in Gloabal Governance: Germany and Japan in the International System, eds. Saori N. Katada, Hanns W. Maull and Takashi Inoguchi. Aldershot and Burlington: Ashgate.

Katō, Hiroyuki. 1997. 'Chūchōki hatten senryaku no sakutei o megutte: Chūgoku kyōiron no keizaitei sokumen (Regarding the Formulation of Medium to Long-Term Development Strategy: The Economic Perspective of the China

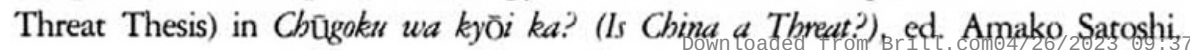


Tokyo: Keisō shobō.

Kawashima, Yutaka. 2003. Japanese Foreign Policy at The Crossraods: Challenges and options for the Twenty-First Century. Washington, D.C.: Brookings Institution Press.

Kayahara, Ikuo. 2001. Anzen hoshō kara mita Nitchū kankei (Security Perspective on Japan-China Relations). Chūgoku 21 10: 75-96.

Kazan-kai. 1980. Nitchū keizai kyōryoku no shin-dankai: Chūgoku no gendaika to enshakkan o megutte (The New Phase of Japan-China Economic Cooperation: Regarding Chinese Modernisation and the Yen Loans). Tōa 152.

Kesavan, K. V. 1990. Japan and the Tiananmen Square Incident: Aspects of the Bilateral Relationship. Asian Survey 30(7): 669-81.

Kidera, Masato. 2008. Sechō jūshi no enjyo moderu wo sekaihe (Spreading Development-centred Aid Model to the world). Gaiko Forum 243: 36-41.

Kojima, Tomoyuki. 1991. Zaisei kiki no naka no kokubōhi zōdai (The Increase in Chinese Defence Expenditure in the Budget Crisis). Tōa. 287: 54-75.

Kojima, Tomoyuki. 1996. Chūgoku no seiji to gaikō wa fukuzatsu sakusō (Complicated Chinese Politics and Diplomacy). Tōa 344: 60.

Kokubun, Ryōsei. 2006. The Shifting Nature of Japan-China Relations after the Cold War in Japan's Relations with China: Facing a Rising Power, eds. Peng Er, Lam. London and New York: Routledge.

Komori, Yoshihisa. 2002. Machigai darake no Chūgoku enjo (Japan's Mistaken China Aid). Chūō kōron. March 2002: 94-109.

Krugman, Paul. 1994. The Myth of Asia's Miracle. Foreign Affairs 73(6): 62-78. Kusano, Atsushi. 2008. Taigaienjyo ni kakawaru taisei no henka to sono haikei (Changes in the Foreign Aid System and Its Background). A paper presented at an annual convention of the Japan Association of International Relations (JAIR) held in October 2008. Tsukuba, Japan.

Levy, Wendy. 1993. Major Returns to Local Firms in Aid to China, Insight: Australian Foreign Affairs and Trade Issues 2(11): 13-14.

Morgenthau, Hans. 1962. A Political Theory of Foreign Aid, American Political Science Review 56(2): 301-9.

Murai, Yoshinori. 1989. Musekinin enjo taikoku Nibon (Japan as an Irresponsible Foreign Aid Power). Tokyo: JICC shuppan-kyoku.

Murai, Yoshinori. 1992. Gaimushō no ODA rinen o tou? (Question the ODA Philosophy of the Ministry of Foreign Affairs?) Sekai 569: 315-324.

Nakajima, Mineo. 1997. Chūgoku wa kyōi ka? (Is China a Threat?). Bōeigaku kenkyū 17: 1-18.

Nakane, Chie. 1972. Tekī̄ no jōken: Nibonteki renzoku no shikō (Conditions of Adaptation: Japanese Thought). Tokyo: Kōdansha.

Narramore, Terry. 2008. China and Europe: Engagement, Multipolarity and Strategy, Pacific Review 21(1): 87-108.

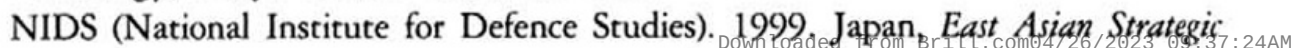


Review 1998-1999. Tokyo.

OECD. 2008. ODA Targets Slipping Out of Reach?, http://www.oecd.org/dac/stats

Okada, Tomihiro. 1994. 2010-nen no Chūgoku keizai zō (The Chinese Economy in 2010). Tōa 322: 21-36.

Ōkita, Saburō. 1979. Japan, China and the United States: Economic Relations and Prospects. Foreign Affairs 57(5): 1090-1110.

Orr, Robert M. 1990. The Emengence of Japan's Foreign Aid Power. Columbia University Press: New York.

Overholt, William H. 2000. China's Economic Squeeze. Orbis 44(1): 13-34.

Poats, Rutherford M. 1986. Twenty-five Years of Development Cooperation: A review. Paris: OECD.

Rix, Alan. 1980. Japan's Economic Aid: Policymaking and Politics. London: Croom Helm.

Sawada, Yasuyuki and Hiroyuki Yamada. 2003. Japan's ODA and Poverty Reduction: A Cross-Donore Comparison and a Case Study of Malaysia in External Factors for Asian Development, ed. Hirohisa Kohama. Singapore: Institute of Southeast Asian Studies.

Schrader, Peter J., Steven W Hook, and Bruce Taylor. 1998. Clarifying the Foreign Aid Puzzle: A Comparison of American, Japanese, French, and Swedish Aid Flows. World Politics 50(2): 294-323.

Shimomura, Yasutami, Junji Nakagawa, and Jun Saitō. 1999. ODA taikō no seiji keizai gaku (Political Economy of the ODA Charter). Tokyo: Yūhikaku.

Sumi, Kazuo. 1989. ODA enjo no genjitsu (Reality of ODA). Tokyo: Iwanami shinsho.

Takagi, Seiichirō. 1994. Chūgoku no keizai taikoku ka to taigai kankei (China as an Emerging Economic Power and its Foreign Relations). Kokusai mondai 406: $60-76$.

Takamine, Tsukasa. 2002. Domestic Determinants of Japan's China Aid Policy: The Changing Balance of Foreign Policymaking Power. Japanese Studies 22(2): 191-206.

Takamine, Tsukasa. 2006. The Political Economy of Japanese Foreign Aid: The Role of Yen Loans in China's Economic Growth and Openness. Pacific Affairs 79(1): 29-48.

Tanaka, Akihiko. 1991. Nitchū kankei 1945-1990 (Japan-China Relations 19451990). Tokyo: Tōkyō daigaku shuppan-kai.

Tow, William T. 1983. Sino-Japanese Security Cooperation: Evolution and Prospects. Pacific Affairs 56(1): 51-83.

Yanai, Shinichi. 1980. Chūgoku to no keizai kyōryoku ni tsuite (Japanese Economic Cooperation with China). A record of lecture given by the then Director of Gaimushō keizai kyōryoku kyoku (Economic Cooperation Bureau of the Foreign Ministry). Tōa 159: 79-81. 
Yee, Herbert and Ian Storey. 2002. Introduction in The China Threat: Perceptions, Myths and Reality, eds. Herbert Yee and Ian Storey. London, New York: RoutledgeCurzon. 1-19.

Yomiuri shinbun (A Japanese daily newspaper), 28 August 2000.

Yomiuri shinbun (A Japanese daily newspaper). 20 December 2001.

Yomiuri shinbun (A Japanese daily newspaper). 11 September 2002.

Whiting, Allen S. 2001. China's Use of Force, 1950-96, and Taiwan. International Security 26(2): 103-31.

Wright-Neville, David. 1991. The Evolution of Japanese Foreign Aid 1955-1990. Monograph No. 2. Melbourne: Monash Development Studies Centre. 


\section{Appendix}

Graph 1. MAjor DAC Members' ODA, 1998-2007 (Net Disbursement)

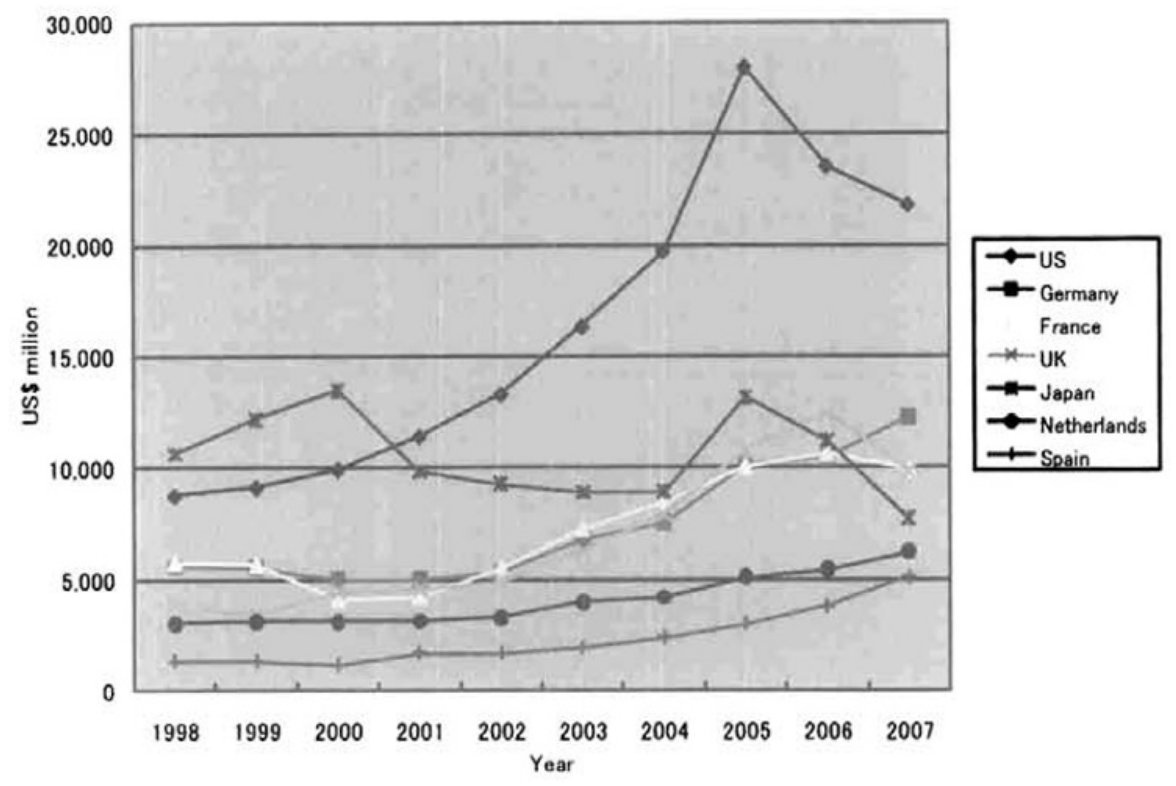




\section{ENDNOTES}

'For more details about ODA net disbursements by the major DAC countries (top seven donors) between 1998 and 2007, see Graph 1 in Appendix.

${ }^{2}$ In this paper Japanese and Chinese personal names are given in the conventional way, with surnames first followed by given name (e.g., Koizumi Junichirŏ and Deng Xiaoping).

${ }^{3}$ This point was clearly expressed in a panel cession presented at an annual convention of the Japan Association of International Relations (JAIR) held in October 2008 in Tsukuba, Japan. Main participants for the cession included prominent Japanese scholars in the field: Kusano Astushi, Fujiwara Kuichi and lokibe Makoto as well as Ogata Sadako, the current President of Japan International Cooperation Agency (JICA).

${ }^{4}$ There are a number of outstanding law suits by Chinese war victims demanding that the Japanese government pay war compensation. For details of some of these law suits, see Asabi shinbun, 29 April 2002; Yomiuri shinbun, 27 August 2002.

'It must be acknowledged, however, that the United States inevitably increased its defence budget after the September 11 attacks to initiate and carry on the war on terfor.

${ }^{6}$ Although Japan's ODA Charter was revised and updated in 2003, the Four Principles stated in the 1992 version of Charter remained the same.

7 The similar tendency in theU.S. aid bureaucracy in which several U.S. aid agencies try to protect their autonomy and to maximize their bureaucratic interests within the government is discussed in (Atwood, McPherson and Natsios 2008). 